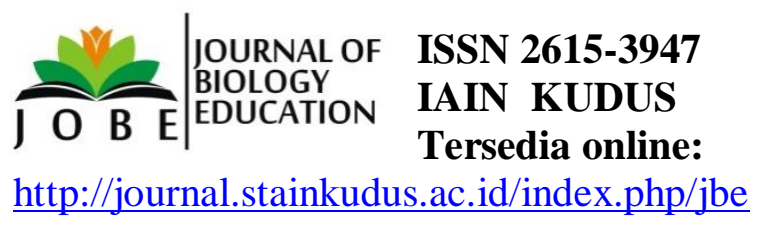

\title{
UBAN DALAM PERSPERKTIF BIOLOGI DAN TEOLOGI
}

\author{
Moh Sholihuddin', Muhamad Jalil ${ }^{2}$ \\ Dosen Pendidikan Agama Islam Institut Agama Islam Negeri Kudus ${ }^{1}$ \\ udinsholahuddin@gmail.com \\ Dosen Tadris Biologi Institut Agama Islam Negeri Kudus ${ }^{2}$ \\ muhamadjalil@stainkudus.ac.id
}

\begin{abstract}
ABSTRAK
Uban merupakan kejadian alamiah yang terjadi pada seorang manusia. Uban selalu diidentikkan bahwa manusia tersebut sudah masuk pada usia tua. Uban yang tumbuh sebelum waktunya tentu akan menjadikan persoalan tersendiri bagi mereka yang ingin tampil sempurna di depan khalayak umum. Hal ini akan mendorong untuk melakukan segala cara untuk menutupi kekurangan tersebut. Tujuan penelitian ini adalah: (a) mendeskripsikan proses terjadinya uban secara biologi fisiologis pada manusia; (b) menjelaskan faktor-faktor yang menyebabkan uban pada manusiaa; (c) nilai pendidikan islam seperti apa yang terjadi dibalik peristiwa uban. Penelitian ini merupakan penelitian kepustakaan (library research). Sumber data dalam penelitan ini adalah Fatwa MUI No 23 Tahun 2012, Buku Anatomi Fisiologi Manusia, dan Fisiologi Hewan. Dalam studi ini data sekundernya adalah buku-buku yang mendukung penulis untuk melengkapi isi sertai interpretasi dari dari sumber data primer. Metode analisis data menggunaka analysis content tipe Holsti. Hasil penelitian menunjukkan bahwa: (1) uban dalam biologi disebabkan kekurangan pigmen melanin sehingga rambut tampak berwarna putih; (2) Uban terjadi karena faktor luar seperti penggunaan bahan kimia yang merusak folikel rambut, stres, genetik, gaya hidup, dan tingkat polusi udara yang tinggi dan faktor instrinsik karena sel melanosit tidak mampu lagi memproduksi pigmen melanin; dan (3) Uban merupakan isyarat bahwa dengan bertambahnya umur maka kematian telah dekat sehingga orang sedapat mungkin menghindari sebanyak mungkin dosa-dosa kecil apalagi dosa besar.
\end{abstract}

Kata kunci: Biologi, Uban, Teologi 


\begin{abstract}
Gray hair is a natural occurrence that occurs in a human being. Gray hair is always identified that the man has entered in old age. Gray hair that grows prematurely will certainly make a problem for those who want to appear perfect in front of the general public. This will encourage to do everything possible to cover the shortfall. The purpose of this study are: (a) describe the process of gray hair in physiological biology in humans; (b) describe the factors that cause gray to humans; (c) the value of Islamic education as what happened behind the gray event. This research is library research (library research). Sources of data in this research is decision of MUI No. 23 of 2012, Book Anatomy of Human Physiology, and Animal Physiology. In this study the secondary data are the books that support the authors to complement the content with interpretation from the primary data source. Data was analyzed by content analysis of holsti. The results showed that: (1) Gray hair in biology caused lack of melanin pigment so the hair looks white; (2) Uses occur due to external factors such as the use of chemicals that damage hair follicles, stress, genetics, lifestyle, and high levels of air pollution and intrinsic factors because melanocyte cells are no longer capable of producing melanin pigment; and (3) Gray hair is a sign that with age the death is so close that people are as much as possible to avoid as many small sins as possible especially the great sins.
\end{abstract}

\title{
Keywords: Biology, Gray hair, Theology
}

\section{PENDAHULUAN}

Uban merupakan kejadian alamiah yang terjadi pada seorang manusia. Uban selalu diidentikkan bahwa manusia tersebut sudah masuk pada usia tua. uban bermakna rambut yang sudah putih atau mulai memutih (KBBI, 2012). Pada diri makhluk hidup terus mengalami pertumbuhan dan perkembangan dari masa prenatal hingga masa tua. ciri fisik ketika seorang memasuki masa tua adalah terjadinya penyusutan organ-organ maupun penting seperti timbulnya uban pada rambut. Ketika masih muda pada umumnya rambut masih berwarna hitam tetapi saat menginjak usia lansia seluruh rambut pada umumnya akan mengalami aus menjadi putih atau kelabu.

Namun dalam kasus tertentu tidak selamanya uban akan muncul pada usia lanjut. Ada juga orang beruban sebelum menginjak usia tua. Orang sekarang ratarata mulai terlihat uban di kepala pada usia sekitar 40 tahun (Ishom, 2017). Dari sumber lain dikatakan bahwa orang Asia akan mengalami pertumbuhan dan 
perkembangan uban pada akhir usia 30 an. Tumbuhnya uban pada usia sebelum itu dapat dianggap terlalu dini atau terlalu cepat tumbuh.

Gaya hidup dituding sebagai salah satu sebab mengapa orang beruban lebih cepat sebelum waktunya. Menurut Adrian (2017), salah satu pemicu uban lebih cepat disebabkan karena kebiasaan merokok. Pada tahun 2009, WHO menyatakan bahwa Indonesia merupakan negara dengan jumlah perokok aktif terbanyak di dunia (Rochayati \& Hidayat, 2015). Penggunaan obat kimia seperti shampo yang sering bergonta-ganti juga dapat menjadi pemicau terjadinya uban lebih cepat. Menurut Huda (2016), penggunaan bahan-bahan kimia menyebabkan banyak resiko, seperti kerusakan pada batang rambut hingga alergi pada kulit kepala. Kosmetik penghitam rambut berbahan alami menjadi alternatif terbaik karena memberikan jaminan keamanan. Lanjut dia mengatakana bahwa banyak anggapan bahwa stres dapat mempercepat faktor penuaan, termasuk tumbuhnya uban lebih dini dari yang seharusnya.

Uban yang tumbuh sebelum waktunya tentu akan menjadikan persoalan tersendiri bagi mereka yang ingin tampil sempurna di depan khalayak umum. Hal ini akan mendorong untuk melakukan segala cara untuk menutupi kekurangan tersebut. Berbagai cara ditempuh, misal dengan disemir hitam, dicat, ditutupi dengan topi atau penutup kepala semacam wig atau rambut palsu.

Menurut komisi fatwa MUI No 23 Tahun 2012, penyemiran pada rambut adalah mubah, jika mengikuti kaidah atau ketentuan yaitu: (a) menggunakan bahan yang halal dan suci; (b) diimaksudkan untuk suatu tujuan yang benar secara syar'i; (c) mendatangkan maslahat yang tidak bertentangan dengan syari'at, (d) materinya tidak menghalangi meresap nya air ke rambut pada saat bersuci; (e) tidak membawa mudharat bagi penggunanya; (f) dan menghindari pemilihan warna hitam atau warna lain yang dapat melahirkan unsur tipu daya (khida') dan/atau dampak negatif lainnya (MUI, 2012). Hukum menyemir rambut yang tidak memenuhi ketentuan sebagaimana ketentuan di atas hukumnya haram. Banyak masyarakat kita yang terjebak dengan kondisi ini, karena penyemiran yang dilakukan tidak mengikuti ketentuan yang digariskan oleh MUI. Penggunaan semir warna hitam supaya tampak lebih mudah merupakan bagian tipu daya dan ini hukumnya jelas kharam. 
Untuk itu dalam penelitian literatur ini akan mencoba menjernihkan bahwa uban merupakan kejadian alamiah yang tidak perlu dirisaukan. Dalam islam uban dianggap sebuah cahaya yang akan menyinari di hari kiamat kelak. Sementara itu dalam kajian biologi, dikatakan bahwa rambut uban hadir akibat kurangnya asupan oksigen yang diterima batang rambut, sarisari makanan yang berada di pembuluh darah tidak dapat diserap oleh batang rambut dan mempengaruhi melanin, maka terjadilah rambut kelabu atau uban (Farah Nurul Huda, 2016). Tujuan penelitian ini adalah: (a) mendeskripsikan peran melamin dalam pembentukan uban secara biologi fisiologis pada manusia; (b) menjelaskan faktorfaktor yang menyebabkan uban pada manusiaa; (c) nilai pendidikan islam seperti apa yang terjadi dibalik peristiwa uban.

\section{METODE PENELITIAN}

Penelitian ini merupakan penelitian kepustakaan (library research), yaitu serangkaian kegiatan yang berkenaan dengan metode pengumpulan data pustaka. Menurut Abdul Rahman Sholeh, penelitian kepustakaan (library research) ialah penelitian yang mengunakan cara untuk mendapatkan data informasi dengan menempatkan fasilitas yang ada di perpus, seperti buku, majalah, dokumen, catatan kisah-kisah sejarah.

Sumber data primer, yaitu data yang diperoleh langsung dari subyek penelitian sebagai sumber informasi yang dicari. Data ini disebut juga dengan data tangan pertama Atau data yang langsung yang berkaitan dengan obyek riset. Sumber data dalam penelitan ini adalah Fatwa MUI No 23 Tahun 2012, Buku Anatomi Fisiologi Manusia, dan Fisiologi Hewan. Dalam studi ini data sekundernya adalah buku-buku yang mendukung penulis untuk melengkapi isi sertai interpretasi dari dari sumber data primer, seperti literatur internet. Metode analisis data menggunaka analysis content tipe Holsti. Tipe ini menyatakan bahwa kajian isi adalah teknik apapun yang digunakan untuk menarik kesimpulan melalui usaha menemukan karakteristik pesan, dan dilakukan secara objektif dan sistematis (Ulahyu Handani, 2017). 


\section{HASIL DAN PEMBAHASAN}

\section{A. Peran Melanin dalam Pembentukan Uban}

Melanin dibentuk oleh melanosit de-ngan bantuan enzim tirosinase yang berperan penting dalam proses pembentuk-annya. Oleh kerja enzim tironase, tiroksin diubah menjadi 3,4 dihidroksiferil alanin (DOPA) dan kemudian menjadi dopa-quinone, yang kemudian dikonversi melalui beberapa tahap transformasi menjadi melanin. Enzim tirosinase dibentuk dalam ribosom, ditransfer dalam lumen retikulum endoplasma kasar, dan melanosit di-akumulasi dalam vesikel yang dibentuk oleh kompleks Golgi (Sinaga, Wangko, \& Kaseke, 2012).

Terdapat empat tahap pada pemben-tukan granula melanin yang matang. Tahap-tahap tersebut secara berurut yaitu: 1) sebuah vesikel dikelilingi oleh membran dan menunjukkan awal proses aktivitas enzim tirosinase dan pembentukan substansi granula halus pada bagian perifernya. Untaian-untaian padat elektron memiliki suatu susunan molekul tirosinase yang rapi pada matrik protein; 2) vesikel (melanosom) berbentuk oval dan bagian dalamnya memperlihatkan filamen-filamen dengan jarak sekitar $10 \mathrm{~nm}$ atau garis lintang dengan jarak sama. Melanin disimpan dalam matriks protein; 3) peningkatan pembentukan melanin mem-buat struktur halus agak sulit terlihat; dan 4) granula melanin matang dapat dilihat dengan mikroskop cahaya dan melanin ini telah mengisi vesikel secara sempurna.

Tirosinase di sintesis dalam retikulum endoplasma kasar dan diakumulasikan dalam vesikel kompleks Golgi. Vesikel bebas sekarang dinamakan melanosom. Sintesis melanin dimulai dalam melanosom tahap II, di mana melanin diakumulasikan dan membentuk melanosom tahap III. Akhirnya struktur ini hilang oleh aktivitas tirosinase dan membentuk granul melanin. Granula melanin bermigrasi ke arah juluran melanosit dan masuk ke dalam keratinosit. Utrastruktur tidak ada yang terlihat. Granula yang matang berbentuk elips, dengan panjang $1 \mu \mathrm{m}$ dan diameter $0,4 \mu \mathrm{m}$ (Kimia Indonesia, 2011)

Sebagian kecil rambut tidak tumbuh dan masih dalam tahap istirahat. Seiring dengan berjalannya waktu, rambut tersebut akan menjadi tua dan mulai berubah warna dari hitam menjadi kelabu dan putih (Medicine Erlangga, 2010). 


\section{B. Faktor-Faktor Penyebab Uban Secara Ilmiah}

Uban atau rambut kelabu dapat terjadi karena beberapa faktor, yaitu ekstrinsik (luar) maupun instrinsik (dalam). Faktor luar antara lain seperti racun akibat penggunaan berbagai kosmetika dengan bahan kimia yang merusak folikel rambut, perubahan iklim, dan tingkat polusi udara yang tinggi (Adrian, 2017). Faktor instrinsik antara lain seperti kurangnya protein sintesa yang ada pada rambut dimana sel melanosit tidak mampu lagi memproduksi pigmen melanin sehingga rambut berkurang kehitamannya. Berikut ini beberapa kondisi yang dapat memengaruhi terbentuknya uban. Faktor-faktor itu dapat dijelaskan sebagai berikut.

\section{Genetik}

Penyebab tumbuhnya uban yang satu ini tidak dapat dielakkan. Orang yang rambutnya sudah memutih atau ubanan walaupun usianya masih muda dapat jadi disebabkan oleh faktor genetik. Itu artinya, orang tua atau kakek-neneknya juga mengalami hal yang sama saat mereka muda.

\section{Kondisi kesehatan}

Menderita penyakit tertentu juga dapat menjadi penyebab tumbuhnya uban. Kondisi bawaan atau kelainan genetik seperti albino, yaitu ketika seseorang hanya memiliki sedikit atau sama sekali tidak memiliki pigmen pada rambut, mata, dan kulit sehingga terlihat putih atau pucat.

Selain albino, vitiligo juga dapat menjadi penyebab tumbuhnya uban. Ini adalah suatu kondisi autoimun yang menyebabkan beberapa bagian pada rambut dan kulit mengalami kehilangan pigmen warna.

Masalah pada kelenjar pituitari atau pada kelenjar tiroid juga dapat menyebabkan uban. Namun setelah kondisi-kondisi tersebut teratasi, warna rambut dapat kembali normal.

Kekurangan nutrisi dapat menjadi penyebab rambut menjadi lebih halus, tipis, dan rapuh serta berubah warna karena penurunan produksi melanin. Contohnya adalah kekurangan vitamin B12 atau anemia pernisiosa. Sindrom Werner juga dapat menyebabkan munculnya uban di usia muda. 


\section{Merokok}

Merokok dapat menjadi faktor penyebab tumbuhnya uban. Bahkan, ada penelitian yang mengungkapkan adanya hubungan antara merokok dengan tumbuhnya uban di usia kurang dari 30 tahun.

\section{Pengobatan}

Pasien yang menjalani radioterapi terkadang rambutnya berubah warna putih, namun akan kembali pada warna asal beberapa waktu kemudian.

Hingga saat ini belum ada produk yang terbukti secara ilmiah mampu memperlambat atau mencegah pertumbuhan uban, mulai dari suplemen, vitamin, protein, atau pola makan tertentu.

\section{Usia}

Secara alami, berubahnya warna rambut menjadi abu-abu atau putih terjadi seiring dengan pertambahan usia atau disebut achromotrichia. Ketika usia kita bertambah, produksi melanin dalam tubuh akan berkurang sehingga menyebabkan munculnya uban. Hal ini diduga disebabkan oleh bertambahnya kerusakan sel karena penuaan.

Biasanya perubahan warna dimulai pada rambut di dalam hidung, disusul rambut pada bagian kepala, jenggot, kemudian rambut di bagian tubuh lain, terakhir rambut pada alis mata.

\section{Uban dalam Perskperktif Pendidikan Islam}

Diceritakan oleh Allamah Sayyid Abdullah bin Alawi Al-Haddad bahwa orang pertama yang mengalami tumbuh uban di kepala adalah Nabi Ibrahim 'alaihissalam. Dalam kitabnya berjudul Sabîlul Iddikâr wal I'tibâr bimâ Yamurru bil Insân wa Yanqadhi Lahu minal A'ma (Ishom, 2017). Sayyid Abdullah AlHaddad menjelaskan bahwa uban memiliki makna sebagai pengingat sebagaimana uraian berikut ini:

Artinya: "Rambut uban (akibat usia) itu merupakan pengingat akan dekatnya ajal, tertutupnya jalan cita-cita dan angan-angan. Ia juga menandakan masa 'berangkat' sudah dekat, dan tidak lama lagi akan 
berpindah. Ada pula yang mengatakan bahwa rambut uban merupakan pertanda tibanya ajal dan penghapus cita-cita. Sebuah pepatah mengatakan 'Alangkah buruknya perbuatan dosa betapa pun kecilnya bila rambut telah mulai beruban.'

Tumbuh dan kembangnya uban di kepala karena faktor usia merupakan petunjuk bahwa dengan bertambahnya umur sesungguhnya saat ajal sudah bergerak mendekat meski hal ini tidak berarti seseorang akan segera meninggal dunia. Dapat jadi saat kematian masih relatif lama. Hal yang perlu diketahui oleh seseorang yang sudah mulai tumbuh uban di kepalanya adalah bahwa uban itu sesungguhnya merupakan "nur" atau cahaya baginya sebagaimana disebutkan dalan hadits Rasulullah SAW sebagai berikut.

Artinya: "Berubahnya rambut seorang Muslim merupakan cahaya baginya." (HR. Tirmidzi dan Nasa-i)

Sejak manusia menyadari bahwa uban telah tumbuh di kepalanya, maka sebaiknya ia tidak lagi terbuai mimpi-mimpi duniawi yang berkepanjangan. Justru seharusnya ia mulai menata dan memantapkan diri dengan cita-cita ukhrawi, seperti bagaimana agar semakin hari dapat semakin istiqamah dalam beribadah kepada Allah SWT. Tidak ada cita-cita yang lebih luhur melebihi cita-cita meraih husnul khatimah.

Tumbuhnya uban di kepala menandakan masa "berangkat" sudah dekat. Apa yang dimaksud dengan "berangkat" adalah mulainya perjalanan menuju fase kehidupan berikutnya, yakni kehidupan di alam barzakh. Alam ini dimulai sejak ajal seseorang tiba lalu dibaringkan di dalam kubur hingga dibangkitkan dengan tiupan sangkakala. Alam barzakh merupakan alam perpindahan atau transisi antara dunia dan akhirat.

Jadi uban di kepala bukan sekedar fenomena biologis biasa yang akan dialami manusia pada umumnya dalam kehidupannya, tetapi di balik itu merupakan isyarat teologis agar seseorang mulai menghindari sebanyak mungkin dosa-dosa kecil apalagi dosa besar. Oleh karena sedemikian penting makna uban di kepala, maka tidak selayaknya rambut putih itu sengaja dipadamkan cahayanya 
dengan mengembalikannya ke warna asli hitam bagi umumnya orang-orang Asia termasuk Indonesia.

Sehubungan dengan itu Sayyid Abdullah Al-Haddad lebih lanjut menjelaskan dalam kitab yang sama pada halaman 44 sebagai berikut.

Artinya: "Mengubah warna uban dengan warna kuning atau merah itu mustahab (disukai), tetapi mengubahnya dengan warna hitam adalah haram kecuali bagi mujahid (orang yang sedang berperang) di jalan Allah sebagai strategi untuk mempertakuti orang-orang kafir."

Dari penjelasan dapat digambarkan bahwa perubahan rambut pada manusia secara normatif ketika telah menginjak usia tertentu mempunyai arti teologis (keagamaan) sebagai pengetuk bahwa saat kematian sesungguhnya telah pelanpelan mendekat. Rambut putih itu sekaligus merupakan cahaya yang diharapakan akan menjadi obor dalam perjalanan pulang kepada Sang Pencipta. Tidak selayaknya cahaya itu dipadamkan untuk tujuan-tujuan duniawi. Maka siapa pun ketika rambutnya telah memutih sebaiknya mulai menata dan memantapkan diri secara istiqamah meraih cita-cita luhur akhir hidup yang husnul khatimah.

\section{SIMPULAN}

Uban dalam biologi disebabkan kekurangan pigmen melanin sehingga rambut tampak berwarna putih. Uban terjadi karena faktor luar seperti penggunaan bahan kimia yang merusak folikel rambut, stres, genetik, gaya hidup, dan tingkat polusi udara yang tinggi dan faktor instrinsik karena sel melanosit tidak mampu lagi memproduksi pigmen melanin. Uban merupakan isyarat bahwa dengan bertambahnya umur maka kematian telah dekat sehingga orang sedapat mungkin menghindari sebanyak mungkin dosa-dosa kecil apalagi dosa besar. 


\section{DAFTAR PUSTAKA}

Adrian, K. (2017). Penyebab Rambut Menjadi Uban. Retrieved July 19, 2018, from https://www.alodokter.com/penyebab-rambut-menjadi-uban

Cegah uban di usia muda. Faculty of Medicine Airlangga University [homepage on the Internet]. Nodate [cited 2010 Jun 03]. Available from: http://www.fk.unair.ac.id/index.php/Focus/cegah-uban-di-usia-muda.html.

Farah Nurul Huda, 5402411044. (2016). Pengelolaan Limbah Biji Buah Mengkudu Dan Teh Hitam Sebagai Penghitam Rambut Beruban (other). Universitas Negeri Semarang. Retrieved from http://lib.unnes.ac.id/24097/

Ishom, M. (2017). Makna Uban di Kepala Menurut Sayyid Abdullah al-Haddad. Retrieved from http://www.nu.or.id/post/read/83416/makna-uban-di-kepalamenurut-sayyid-abdullah-al-haddad-

KBBI, K. (2012). Arti kata uban - Kamus Besar Bahasa Indonesia (KBBI) Online. Retrieved July 19, 2018, from https://kbbi.web.id/uban

Kimia Indonesia [homepage on the internet]. Nodate [cited 2011 Apr 18]. Available from: http://indonesiakimia. blogspot.com/2011/06/melanin.html

MUI. (2012). Hasil Ijtima' Ulama 2018. Retrieved July 19, 2018, from http://mui.or.id/wp-content/uploads/2017/02/Menyemir-Rambut.pdf

Rochayati, A. S., \& Hidayat, E. (2015). Faktor-Faktor Yang Mempengaruhi Perilaku Merokok Remaja di Sekolah Menengah Kejuruan Kabupaten Kuningan. Jurnal Keperawatan Soedirman, 10(1), 1-11. https://doi.org/10.20884/1.jks.2015.10.1.587

Sinaga, R., Wangko, S., \& Kaseke, M. (2012). Peran Melanosit Pada Proses Uban, 4(3), 4-12.

Ulahyu Handani, F. (2017). Konsep Etika Guru Dalam Pendidikan Islam (tela'ah Atas Kitab Adabul 'alim Wal Muta'allim Karya Kh. Hasyim Asy'ari) (skripsi). STAIN Kudus. Retrieved from http://eprints.stainkudus.ac.id/406/ 